\title{
Combining Ability Analysis of Yield Components in Cucumber
}

\author{
Ana I. López-Sesé and Jack Staub ${ }^{1}$ \\ U.S. Department of Agriculture, Agricultural Research Service, Vegetable Crops Unit, Department of \\ Horticulture, 1575 Linden Drive, University of Wisconsin-Madison, WI 53706
}

\begin{abstract}
AdDITIONAL INDEX WORDS. Cucumis sativus, Cucumis hardwickii, general combining ability, half-diallel, multiple lateralbranching, specific combining ability, vegetable breeding, sex expression

Abstract. Three U.S.-adapted Cucumis sativus var. sativus L. lines and one $C$. sativus var. hardwickii (R.) Alef.-derived line were crossed in a half-diallel design to determine their combining ability for several yield-related traits (yield components). Six $F_{1}$ progenies were evaluated in a randomized complete block design with eight replications in 1999 and 2000 for fruit number and length/diameter ratio (L:D), lateral branch number, number of female flowering nodes, and days to anthesis. Combining ability was significantly influenced $(p<0.05)$ by year for most of the horticultural traits examined. General combining ability (GCA) was significant for all traits in each year. Specific combining ability (SCA) was significant in magnitude and direction for only fruit number and days to anthesis. Data indicate that the $C$. sativus var. hardwickii-derived inbred line WI 5551 possessed SCA for yield component traits, and thus maybe useful for improving fruit yield in commercial cucumber.
\end{abstract}

Yields of multiplehand-harvest U.S. pickling cucumber(Cucumis sativus var. sativus L.; hereafter referred to as C. s. var. sativus) have increased dramatically since $1940(\approx 5 \%$ annual average increase $)$ (USDA Agricultural Statistics, 1998). Improved cultural practices, the introduction of gynoecy, and the intogression of yield and disease resistance genes in elite breeding lines (Cargill, 1962; Peterson, 1960; T.C. Wehner, personal communication) have resulted in a 3-fold increase in average yield from $4,076 \mathrm{~kg} \cdot \mathrm{ha}^{-1}$ in 1920 to $12,550\left(\mathrm{~kg} \cdot \mathrm{ha}^{-1}\right)$ in 1980 (USDA Agricultural Statistics, 1940, 1981). Nevertheless, with the exception of perhaps some unique processing hybrids that are adapted to specific growing environments, average yield has reached a plateau in the past 15 years $\left(\approx 13,400 \mathrm{~kg} \cdot \mathrm{ha}^{-1} 1997\right.$; USDA Agricultural Statistics, 1998).

Several biological factors limit cucumber yield. The development of the first fertilized fruit in cucumber inhibits the enlargement of subsequent fruit (McCollum, 1934; Tiedjens, 1928). This inhibitory response is sustained until the enlarging fruit are removed. First fruit inhibition and the narrow genetic base of cucumber (Meglic et al., 1996) are important factors that limit cucumber yield (El-Shawaf and Baker, 1981; Gharderi and Lower, 1979, 1981; Smith and Lower, 1978).

Smith and Lower (1978) suggested that the incorporation of genes from exotic, sequential fruiting genotypes might increase genetic diversity and the fruit setting potential of commercial pickling cucumber. Selection for several yield-related traits, such as gynoecy and plant architecture, increase the number of fruitbearing branches per plant (Wehner, 1989). Likewise, several exotic or semi-exotic varieties have been used in matings with standard lines in order to broaden the narrow genetic base of commercial cucumber (Lower et al., 1982). Two germplasm sources that have been used by cucumber breeders to broaden the diversity of cultivated cucumber are C. sativus var. hardwickii (R) Alef. (hereafter referred to as C. s. var. hardwickii) a feral relative of C. s. var. sativus (Horst and Lower, 1978; Kupper and Staub, 1988), and a more recently developed monoecious $C$. $s$. var. sativus-derived inbred line 'Arkansas Little Leaf' (experi-

Received for publication 4 Mar. 2002. Accepted 23 Aug. 2002. Mention of a trade name, proprietary product, or specific equipment does not constitute a guarantee or warranty by the USDA and does not imply its approval to the exclusion of other products that may be suitable.

${ }^{1}$ To whom reprint requests should be addressed. mental line H-19; University of Arkansas, Fayetteville) derived from a spontaneous mutation (Goode et al., 1989). Both sources possess a multiple lateral branching and sequential fruiting habit not present in C. s. var. sativus lines.

The gynoecious or predominantly female, multiple disease resistant (angular leaf spot, anthracnose, scab, cucumber mosaic virus, downy mildew, and powdery mildew) C. s. var. hardwickiiderived line WI 5551 was released by the U.S. Department of Agriculture, Agricultural Research Service in 1992 to provide breeders with multiple branching, sequential fruiting germplasm for cucumber improvement (Staub et al., 1993). The yield advantage of hardwickii-derived germplasm, such as line WI 5551, is more pronounced at relatively low plant densities (e.g., 29,000 vs. 58,000 plants/ha) (Frederick and Staub, 1989), and the fruit yield of generations derived from C. s. var. sativus $\times$ C. s. var. hardwickii crosses (e.g., $\mathrm{F}_{2}, \mathrm{~F}_{2} \mathrm{~S}_{1}$, and $\mathrm{BC}_{1}$ ) can differ from the parental lines at particular plant densities (Delaney and Lower, 1987; Lower et al. 1982; Staub and Kupper, 1985). Line WI 5551 was found to contribute significantly, as reflected in both general (GCA) and specific (SCA) combining ability, to hybrid cucumber yield when crossed in combination with elite $C$. s. var. sativus germplasm such as WI 1701 and WI 2712 (Fredrick and Staub, 1989). However, significant genotype by environment (several plant densities examined) interactions were observed for yield components (e.g., days to anthesis and early harvest fruit number) when these hybrids and C. s. var. hardwickii-derived lines were evaluated under open-field conditions. Moreover, the fruit quality of line WI 5551 and its derived hybrids was inferior to that of the elite hybrids examined.

The multiple branching line $\mathrm{H}-19$ was given a plant variety protection (PVP) certificate in 1993 based on its miniature-sized leaves (mature blade of the third leaf from the terminal whorl being $43 \mathrm{~mm}$ long and $63 \mathrm{~mm}$ wide) and the diameter of its stems (one-third to one-half less than standard cucumber varieties) (Staub et al., 1996). Given the distinctly different origins of these lines, it would be useful to compare the horticultural performance of WI 5551 and H-19 when used in hybrid combination (i.e., GCA and SCA) with elite lines in different growing environments. Therefore, a study was designed to compare the combining ability of WI 5551 and H-19 with elite C. s. var. sativus lines of contrasting plant architecture for several yield components. 


\section{Materials and Methods}

Plant material. Four diverse cucumber inbred lines were selected for crossing in a $4 \times 4$ half-diallel design to produce six F1 hybrids (Table 1 ; reciprocals not included). These lines were highly inbred $\left(>S_{10}\right)$, and consisted of the gynoecious, multiple disease resistant, standard-sized leaf, high quality $C$. $s$. var. sativus lines GY14 (Clemson University, Clemson, S.C.) and GY-7 (derived from the experimental line G421; R.L. Lower, University of Wisconsin, Madison, Wis.). The growth habit of GY14 is indeterminate and that of GY-7 is determinate. Both lines produce one to two primary lateral branches. In contrast, lines WI 5551 and H-19 are indeterminate, multiple lateral branched ( 3 to 12 branches depending on plant population), and $\mathrm{H}-19$ possesses miniature-sized leaves. Seed of GY-7 was obtained from R.L. Lower, University of Wisconsin, Madison, and seed of H-19, WI 5551, and GY14 was obtained from the USDA, ARS, breeding program, Madison, Wis.

Field Evaluation. In the summer of 1999 and 2000, the four parental lines and their six $\mathrm{F}_{1}$ families were planted at the University of Wisconsin experimental station at Hancock, Wis., in a Planefield loamy sand (Typic Uipsament; sandy, mixed, mesic). Eight replications were arranged in a randomized complete block design. In each replication (rep), twelve individuals of each accession were spaced $12.5 \mathrm{~cm}$ within a row (plot) on $1.5 \mathrm{~m}$ centers $(53,000$ plants/ha). Plants were maintained under overhead irrigation with standard cultural practices (standard fertilization, spraying, and hand cultivation).

Data were collected from 12 plants per plot of each accession for the following characters (horticultural traits).

1) Days to anthesis = the number of days from planting to the appearance of a fully opened corolla in at least one flower.

2) Number of female nodes $=$ sex expression was recorded for flowers in each of the first 10 nodes, starting with the first flowering node and nodes with both staminate and pistillate flowers were counted as staminate.

3) Number of fruit $=$ fruit were harvested three times at 50,60, and 70 days after planting.

4) Fruit length to diameter ratio $(L: D)=$ seven to ten fruit were randomly selected at each harvest, and their lengths and diameters were measured to determine mean L:D.

5) Number of lateral branches $=$ the total number of primary lateral branches was recorded at first harvest.

STATISTICAL ANALYSES. Analyses of variance (ANOVA) of data were performed over years and within a year as dictated by combined year analyses. Initially, these analyses tested whether there was a difference between years for the traits examined. Homogeneity of variances between and within locations was also tested. Arcsine square root transformation was applied to number of pistillate node data to increase the homogeneity of variance. Subsequent analyses were based on the assumption that parental genotypes were homozygous and that variances were homogeneous (Simmonds, 1979). Where appropriate, ANOVA was followed by LSD mean comparison of morphological trait values within and between years using the statistical program SAS (SAS Institute, 1992). Pearson correlation coefficients $(r)$ were then calculated among all traits.

For the combining ability analysis (GCA), measurements of plants within each plot were averaged, and means were used as experimental units for analysis by the computer program Diallel (Burrow and Coors, 1994). Data were analyzed to obtain GCA and SCA estimates using $F_{1}$ hybrid and parental data according to Comstock and Robinson (1948). Reciprocal progeny were not examined because previous studies indicated that reciprocal differences in such crosses were not significant for the traits evaluated (Staub and Kupper, 1985). Because the parents used were specifically selected and of limited number, they were considered fixed effects while blocks and experimental error were considered random. Conclusions drawn from this study are only applicable to the parents and environment used herein (Hallauer and Miranda, 1981). The model used, based on Griffing (1956), was $\mathrm{x}_{\mathrm{ijk}}=\mu+\mathrm{g}_{\mathrm{i}}+\mathrm{g}_{\mathrm{j}}+\mathrm{s}_{\mathrm{ij}}$ $+b_{k}+\varepsilon_{i j k}$, where $x_{i j k}=$ the phenotypic value of the mating of the $i^{\text {th }}$ parent with the $j^{\text {th }}$ parent in the $\mathrm{k}^{\text {th }}$ block; $\mu=$ population mean; $\mathrm{g}_{\mathrm{i}}=$ GCA effect for the $i^{\text {th }}$ parent; $g_{j}=$ GCA effect for the $j^{\text {th }}$ parent; $s_{i j}=$ SCA effect for parents $i^{\text {th }}$ and $j^{\text {th }} ; b_{k}=$ effect of the $\mathrm{k}^{\text {th }}$ block, and $\varepsilon_{\mathrm{ijk}}$ $=$ error (residual). The model assumes that epistasis and genotype by environment interaction are not significant (Kupper and Staub, 1988). Relative importance of GCA when compared to SCA was calculated as follows: $\mathrm{MS}_{\mathrm{ij}} /\left(\mathrm{MS}_{\mathrm{ij}}+\mathrm{MS}_{\mathrm{ix}}\right)$, where $\mathrm{MS}_{\mathrm{ij}}$ represents the mean square of the main effects of the $i$ and $j$ parents (GCA estimates), and the $\mathrm{MS}_{\mathrm{ixj}}$ component represents the mean square of the interaction effect between them (SCA estimates). When the resultant value of this ratio (GCA versus SCA) is near one, the parental performance in a cross is predictable based on GCA alone (Baker, 1978). Coefficients of determination $\left(R^{2}\right)$ were also computed.

\section{Results}

An initial analysis revealed that significant differences $(P<0.05)$ existed between years for all of the traits examined (data not shown). In general, trait means were higher during 2000 than in 1999, and, thus, data are presented by year. Year analyses indicated that parental lines were consistently different $(P<0.05)$ for all traits examined (Table 1). Differences among blocks within years were also detected $(P<0.05)$ for all traits, except days to anthesis and L:D ratio in both years (first and second harvests separately), and fruit number at first harvest in 2000 (Table 1).

Mean squares for GCA and SCA were significant $(P<0.05)$ for all traits examined in each year (Table 2). Relative importance of GCA versus SCA was very high for all traits in both years (values $>0.75$ ), except for fruit number at first harvest in 2000 (Table 2). Differences in GCA (Table 3) and SCA (Table 4) for most traits were observed among lines when they were mated to a common parent indicating that considerable genetic variation existed among the lines examined. Although $R^{2}$ values were high $\left(R^{2}>0.40\right)$ for all traits studied in both years, values were higher in 1999 than in 2000 for most of the traits examined (Table 2). Values were relatively high and consistent over year $\left(R^{2}>0.80\right)$ for number of lateral branches and number of female nodes.

DaYs to anTHESIS. The number of days to anthesis differed among years with entries flowering later in 2000 (Table 1). Differences between parental lines were significant and experimental coefficients of variation for this trait were remarkably low (Table 1 ). Line WI 5551 tended to flower later than the other parental lines tested. This trait was transmitted to some $\mathrm{F}_{1}$ hybrid progeny such as WI 5551 x GY14 (41.6 and $45.1 \mathrm{~d}$ in 1999 and 2000, respectively), which was the latest flowering of the hybrid progeny tested. The monoecious line $\mathrm{H}-19$ was the earliest flowering line among the parental lines examined (Table 1). Earliness in flowering was also observed in H-19 x WI 5551 hybrid progeny (i.e., 40 and $42.9 \mathrm{~d}$ in 1999 and 2000, respectively) (Table 1).

The GCA effects were slightly more important than SCA effects for days to flowering as estimated by the GCA vs. SCA parameter (0.75 and 0.62) (Table 2). The GCA of line WI 5551 was the largest 
Table 1. Morphological traits of parental lines and $\mathrm{F}_{1}$ hybrids in cucumber (Cucumis sativus $\mathrm{L}$.) presented by year.

\begin{tabular}{|c|c|c|c|c|c|c|c|c|c|c|}
\hline \multirow[b]{2}{*}{ Line } & \multirow{2}{*}{$\begin{array}{l}\text { Days to } \\
\text { anthesis }\end{array}$} & \multicolumn{7}{|c|}{ Harvest } & \multirow{2}{*}{$\begin{array}{c}\text { Lateral } \\
\text { branch } \\
\text { no. }\end{array}$} & \multirow{2}{*}{$\begin{array}{c}\text { Female } \\
\text { nodes } \\
\text { (no.) }\end{array}$} \\
\hline & & Fruit no. & $\mathrm{L}: \mathrm{D}^{\mathrm{y}}$ & Fruit no. & $\mathrm{L}: \mathrm{D}$ & $\begin{array}{c}\text { Three } \\
\text { Fruit no. }\end{array}$ & Fruit no. & $\overline{L: D}$ & & \\
\hline GY-7 & 40.4 & 0.8 & 2.5 & 1.8 & 2.5 & 1.8 & 4.5 & 2.5 & 0.4 & 93.9 \\
\hline GY14 & 40.0 & 1.2 & 1.7 & 2.2 & 2.2 & 1.8 & 5.2 & 1.9 & 1.5 & 89.5 \\
\hline H-19 & 36.5 & 1.7 & 3.1 & 2.8 & 2.9 & 3.5 & 8.0 & 3.0 & 4.2 & 0.5 \\
\hline GY-7 x H-19 & 40.1 & 1.0 & 2.5 & 2.1 & 2.7 & 2.2 & 5.2 & 2.6 & 0.8 & 85.0 \\
\hline GY-7 x WI 5551 & 39.3 & 1.2 & 2.3 & 2.4 & 2.3 & 2.5 & 6.1 & 2.3 & 1.6 & 85.0 \\
\hline GY14 x H-19 & 38.8 & 0.9 & 2.3 & 2.3 & 2.4 & 2.0 & 5.2 & 2.3 & 1.9 & 64.1 \\
\hline WI 5551 x GY14 & 441.6 & 1.0 & 2.0 & 2.3 & 2.2 & 2.6 & 5.9 & 2.1 & 2.3 & 79.4 \\
\hline H-19x WI 5551 & 40.0 & 0.8 & 2.3 & 2.1 & 2.5 & 3.6 & 6.5 & 2.4 & 2.7 & 41.4 \\
\hline GY14 & 43.0 & 2.1 & 2.4 & 2.3 & 2.4 & 2.3 & 6.7 & 2.3 & 1.5 & 95.5 \\
\hline H-19 & 43.9 & 0.1 & 3.5 & 2.2 & 2.8 & 3.8 & 6.0 & 2.9 & 4.4 & 0.0 \\
\hline WI 5551 & 46.0 & 0.5 & 2.5 & 3.7 & 2.3 & 4.8 & 9.1 & 2.3 & 2.1 & 34.8 \\
\hline GY-7 x GY14 & 43.8 & 2.4 & 2.4 & 2.4 & 2.7 & 2.6 & 7.4 & 2.5 & 2.1 & 98.0 \\
\hline GY-7 x H-19 & 44.6 & 2.6 & 2.6 & 2.8 & 2.9 & 3.1 & 8.5 & 2.6 & 2.0 & 97.5 \\
\hline GY-7 x WI 5551 & 45.0 & 2.7 & 2.4 & 3.5 & 2.7 & 3.6 & 9.7 & 2.5 & 2.3 & 97.3 \\
\hline GY14 x H-19 & 44.1 & 2.2 & 2.7 & 2.7 & 2.7 & 4.1 & 9.0 & 2.5 & 2.1 & 86.8 \\
\hline WI 5551 x GY14 & 445.1 & 2.0 & 2.5 & 2.7 & 2.5 & 3.9 & 8.6 & 2.4 & 2.9 & 93.0 \\
\hline H-19x WI 5551 & 42.9 & 2.7 & 2.7 & 3.7 & 2.9 & 5.6 & 12.0 & 2.7 & 3.1 & 51.3 \\
\hline $\operatorname{LSD}_{(0.05)}$ & 1.4 & 0.6 & 0.3 & 0.8 & 0.2 & 1.3 & 2.2 & 0.1 & 0.3 & 5.7 \\
\hline $\mathrm{CV}(\%)$ & 3.1 & 29.1 & 27.9 & 31.5 & 8.2 & 20.5 & 20.3 & 4.3 & 41.0 & 24.5 \\
\hline
\end{tabular}

${ }^{\mathrm{z} A v e r a g e ~ o v e r ~ t h r e e ~ h a r v e s t s . ~}$

${ }^{\mathrm{y}} \mathrm{L}: \mathrm{D}=$ length to diameter ratio of randomly selected fruit from 7 to 10 plants per experimental unit (line).

Table 2. Mean Squares from the analysis of variance of combining ability in 2 years of morphological traits of parental lines and $\mathrm{F}_{1}$ hybrids in cucumber (Cucumis sativus L.).

\begin{tabular}{|c|c|c|c|c|c|c|c|c|c|c|c|}
\hline \multirow{2}{*}{$\begin{array}{l}\text { Source of } \\
\text { variation }\end{array}$} & \multirow[b]{2}{*}{$\mathrm{df}^{\mathrm{z}}$} & \multirow{2}{*}{$\begin{array}{l}\text { Days to } \\
\text { anthesis }\end{array}$} & \multicolumn{7}{|c|}{ Harvest } & \multirow{2}{*}{$\begin{array}{c}\text { Lateral } \\
\text { branch } \\
\text { no. }\end{array}$} & \multirow{2}{*}{$\begin{array}{l}\text { Female } \\
\text { nodes } \\
(\text { no. })^{\mathrm{w}}\end{array}$} \\
\hline & & & Fruit no. & $\overline{\mathrm{L}: \mathrm{D}^{\mathrm{y}}}$ & Fruit no. & L:D & $\frac{\text { Three }}{\text { Fruit no. }}$ & Fruit no. & $\overline{L: D}$ & & \\
\hline Replications & 7 & $0.18^{\mathrm{NS}}$ & $0.75^{* *}$ & $0.67^{* *}$ & $0.27^{* *}$ & $0.03^{\mathrm{NS}}$ & $0.64^{*}$ & $3.79^{* *}$ & $0.07^{\mathrm{NS}}$ & $0.34^{\mathrm{NS}}$ & $0.05^{\mathrm{NS}}$ \\
\hline Crosses & 9 & $14.53^{* *}$ & $3.91^{* *}$ & $1.06^{* * *}$ & $2.20^{* * *}$ & $0.37^{* *}$ & $4.97^{* *}$ & $26.96^{* *}$ & $0.68^{* * *}$ & $9.47^{* * *}$ & $1.30^{* *}$ \\
\hline GCA & 3 & $26.20^{* * *}$ & $4.81^{* *}$ & $2.75^{* *}$ & $4.11^{* *}$ & $1.05^{* *}$ & $13.72^{* * *}$ & $61.07^{* *}$ & $1.89^{* * *}$ & $22.72^{* * *}$ & $3.41^{* * *}$ \\
\hline GCA vs. $\mathrm{SCA}^{\mathrm{v}}$ & & 0.75 & 0.58 & 0.93 & 0.77 & 0.97 & 0.96 & 0.86 & 0.96 & 0.89 & 0.93 \\
\hline$R^{2}$ & & 0.63 & 0.73 & 0.84 & 0.50 & $\begin{array}{c}0.67 \\
2000\end{array}$ & 0.74 & 0.77 & 0.77 & 0.84 & 0.86 \\
\hline Replications & 7 & $2.37^{\mathrm{NS}}$ & $0.45^{\mathrm{NS}}$ & $0.06^{\mathrm{NS}}$ & $2.89 * *$ & $0.09^{\mathrm{NS}}$ & $6.24^{* *}$ & $21.71^{* * *}$ & $0.05^{* *}$ & $0.72^{* *}$ & $0.01^{\mathrm{NS}}$ \\
\hline Crosses & 9 & $7.47^{* *}$ & $6.36^{* *}$ & $0.67^{* *}$ & $2.93^{* *}$ & $0.27^{* *}$ & $10.57^{* *}$ & $26.94^{* *}$ & $0.27^{* *}$ & $6.89^{* * *}$ & $1.95^{* *}$ \\
\hline$R^{2}$ & & 0.41 & 0.75 & 0.58 & 0.48 & 0.51 & 0.58 & 0.54 & 0.79 & 0.82 & 0.97 \\
\hline
\end{tabular}

$\overline{{ }^{2} \mathrm{df}}=$ degrees of freedom.

${ }^{y} \mathrm{~L}: \mathrm{D}=$ length/diameter ratio of randomly selected fruits from 7 to 10 plants per experimental unit (line).

${ }^{x}$ Average over three harvests.

${ }^{\mathrm{w}}$ Arcsine square root transformation of the data.

${ }^{v}$ GCA vs. SCA = GCA/(GCA + SCA $)$.

Ns, *** Nonsignificant or significant at $P=0.05$ and 0.01 , respectively. 
among the lines examined in both years (Table 3). For GY14, these values were variable depending on year. Generally, SCA values were inconsistent (Table 4). However, positive SCA values were evident in the crosses GY-7 x H-19 and WI $5551 \times$ GY14 in both years.

Fruit NUMBER. Generally, mean fruit number was higher in 2000 than in 1999 (Table 1). The cumulative yield of line WI 5551 was higher than the other parental lines tested. Likewise, the cumulative yield of hybrid progeny derived from WI 5551 was higher than those developed using other parental lines.

The relative importance of GCA vs. SCA for fruit number was relevant after the first harvest, with values higher than 0.75 (Table 2). The GCA estimates for this trait were variable in magnitude and direction depending on the harvest (Table 3). Estimates of GCA for fruit number were most variable in Harvest 1, but were relatively consistent in Harvest 3 and cumulative three-harvest. In most instances, GCA estimates for this trait were positive and relatively high for line WI 5551, but negative for lines GY-7 and GY14 (Table 3 ). As determined from progeny performance, hybrids from GY-7 X WI 5551 yielded more fruit than those from the GY-7 x H-19 (Table 1). Fruit number SCA estimates of parental lines varied in magnitude and direction depending on harvest and year (Table 4). The $R^{2}$ values for fruit number per plant were moderate to high $(0.48$ to 0.77 ) depending on the harvest and year (Table 2).

FruIT SHAPE. Length/diameter ratio (L:D) values were variable depending on the harvest and year (Table 1). However, L:D values

Table 3. Estimates of general combining ability effects (GCA) in 2 years for traits examined in cucumber (Cucumis sativus L.).

\begin{tabular}{|c|c|c|c|c|c|c|c|c|c|c|}
\hline \multirow[b]{2}{*}{ Parent/trait } & \multirow{2}{*}{$\begin{array}{l}\text { Days to } \\
\text { anthesis }\end{array}$} & \multicolumn{7}{|c|}{ Harvest } & \multirow{2}{*}{$\begin{array}{c}\text { Lateral } \\
\text { branch } \\
\text { no. }\end{array}$} & \multirow{2}{*}{$\begin{array}{c}\text { Female } \\
\text { nodes } \\
\text { (no.) }\end{array}$} \\
\hline & & Fruit no. & $\mathrm{L}: \mathrm{D}^{\mathrm{z}}$ & Fruit no. & L:D & $\frac{\text { Three }}{\text { Fruit no. }}$ & Fruit no. & L:D & & \\
\hline GY-7 & 0.26 & -0.24 & 0.08 & -0.29 & 0.03 & -0.45 & -1.00 & 0.06 & -0.92 & 0.24 \\
\hline GY14 & 0.30 & -0.15 & -0.26 & -0.14 & -0.12 & -0.46 & -0.78 & -0.20 & -0.08 & 0.16 \\
\hline H-19 & -1.09 & -0.06 & 0.29 & 0.05 & 0.19 & 0.35 & 0.33 & 0.25 & 0.68 & -0.35 \\
\hline GY-7 & 0.06 & 0.33 & -0.07 & -0.18 & 0.07 & -0.81 & -0.66 & 0.03 & -0.53 & 0.29 \\
\hline GY14 & -0.37 & 0.18 & -0.12 & -0.26 & -0.09 & -0.43 & -0.49 & -0.09 & -0.27 & 0.20 \\
\hline H-19 & -0.31 & -0.32 & 0.27 & -0.10 & 0.12 & 0.43 & 0.00 & 0.16 & 0.70 & -0.36 \\
\hline WI 5551 & 0.62 & -0.19 & -0.08 & 0.54 & -0.09 & 0.81 & 1.15 & -0.09 & 0.10 & -0.14 \\
\hline
\end{tabular}

${ }^{\mathrm{z}} \mathrm{L}: \mathrm{D}=$ length/diameter ratio of randomly selected fruits from 7 to 10 plants per experimental unit (line).

${ }^{\mathrm{y}}$ Average over three harvests.

Table 4. Estimates of specific combining ability effects (SCA) in 2 years for traits examined in cucumber (Cucumis sativus L.).

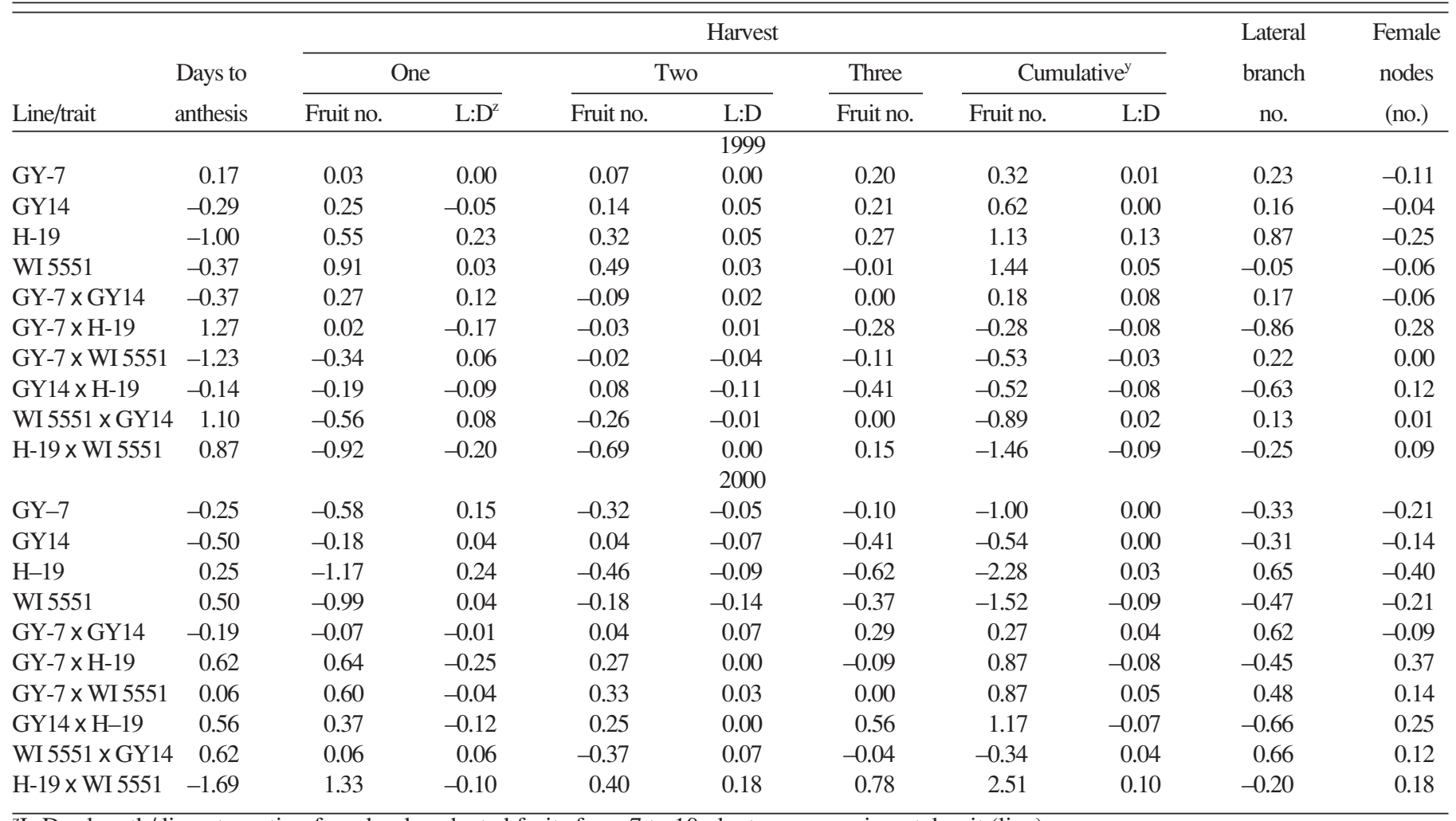

${ }^{\mathrm{z}} \mathrm{L}: \mathrm{D}=$ length/diameter ratio of randomly selected fruits from 7 to 10 plants per experimental unit (line).

${ }^{\mathrm{y}}$ Average over three harvests. 
were generally higher in 2000 than in 1999. In most cases, comparatively high L:D values were recorded in fruit harvested from line $\mathrm{H}-$ 19 (2.8 to 3.5) or progeny derived from $\mathrm{H}-19$ (2.3 to 2.9). In contrast, fruit L:D values of GY14 (1.7 to 2.4 ) or its derived progeny were relatively low (2.0 to 2.7 ).

The GCA effects were very important in comparison to SCA effects for L:D ratio in individual and cumulative harvest estimates in both years, as estimated by the GCA vs. SCA parameter (Table 2 ). The magnitude and direction of GCA estimates for L:D ratio were consistent over harvest and years. Estimates of GCA were highest for $\mathrm{H}-19$ regardless of year (Table 3). In contrast, GCA estimates for GY14 and WI 5551 were comparatively low. Estimates of SCA were consistent for L:D ratio over harvests (Table 4). Positive SCA directional effects were obtained for those crosses involving GY14 (i.e., GY14 x GY-7 and GY14 x WI 5551) during both years. Consistently negative SCA directional effects were obtained for crosses involving line $\mathrm{H}-19$. The $R^{2}$ values for L:D ratio were moderate to high $\left(R^{2}>0.50\right)$ depending on the harvest and year (Table 2).

LATERAL BRANCH NUMBER. While line GY-7 possessed the lowest number of lateral branches each year, the highest number of branches was recorded in line H-19 (Table 1). Although the mean number of lateral branches in the hybrids examined varied dramatically between years, it was consistently higher in 2000 than in 1999. For both years, the progeny of the hybrid GY-7 x H-19 had the lowest number of lateral branches, and the highest branch number was recorded in H-19x WI 5551 progeny. In 2000, the mean number and range of branches in several hybrids having WI 5551 as a common parent (e.g., WI 5551 x GY14 and GY-7 x WI 5551) was greater than the high branching parent involved (WI 5551).

Mean comparisons of lateral branch number in progeny having a common parent suggest that the combining ability of parental lines differed (Table 1). The GCA and SCA effects were significant and consistent in both years (Tables 2, 3, 4), with GCA effects being relatively more important than SCA, as estimated by GCA vs. SCA parameter (0.80 and 0.89) (Table 2$)$. In both years, the highest and lowest GCA value for this trait was calculated for lines H-19 and GY-7, respectively (Table 3). Despite the high branch numbers observed in line H-19, lines GY-7 and GY14 produced greater branch numbers in crosses with WI 5551 than with H-19, regardless of evaluation year (Table 1). Lines WI 5551 and GY-7 had a relatively high and low GCA for this trait, respectively (Table 3). Although negative SCA values were detected for the line WI 5551, its hybrids possessed a positive and relatively high SCA for this trait (Table 4). Despite its potential for contributing multiple-lateral branching to its progeny, the SCA effects associated with $\mathrm{H}-19$ were negative in its hybrids (Table 4). This negative SCA effect was most pronounced in progeny derived from crossings using line GY-7 as a parent. High and consistent $R^{2}$ values (0.82 in 1999 and 0.84 in 2000) were detected for this trait (Table 4).

SEX EXPRESSION. While the number of female nodes was consistent among entries over years, higher frequencies were recorded in 2000 than in 1999 (Table 1). The highest number of female nodes was always observed in the gynoecious parental line GY-7. In contrast, the lowest number of female nodes was observed in the monoecious line H-19. Hybrid progeny derived from GY-7 produced the highest number of female nodes per plant when compared to the other hybrids examined. Female nodes per plant in hybrids derived from line GY-7 were not different from the parental gynoecious line (Table 1). The number of female nodes in all hybrid progenies and gynoecious parental lines was relatively high $(>60 \%)$ when compared to the monoecious line $\mathrm{H}-19$ or to progeny derived from $\mathrm{H}-19 \times$ WI 5551 matings $(<52 \%)$.

The GCA effects were more important than SCA effects for gynoecy, as estimated by GCA vs. SCA parameter (0.93 and 0.86) (Table 2). The estimates of GCA for numbers of female nodes were consistent in magnitude and direction across years. Positive GCA values for this trait was associated with the gynoecious lines GY-7 and GY14 (Table 3). While GCA estimates for line GY-7 were consistently high, estimates for line H-19 were comparatively low, regardless of year. The SCA estimates were consistent over years with negative values observed for all parental lines and the cross GY-7 x GY14 (Table 4), and positive SCA values observed on the remaining hybrids. While the highest SCA values in both years for gynoecy were associated with the cross GY-7 x H-19, the lowest values were associated with $\mathrm{H}-19$ and the cross GY-7 x GY14.

Table 5. Correlation coefficients in 1999 (lower diagonal) and 2000 (upper diagonal) among morphological traits of parental lines and $\mathrm{F}_{1}$ hybrids of cucumber (Cucumis sativus L.).

\begin{tabular}{|c|c|c|c|c|c|c|c|c|c|c|}
\hline \multirow[b]{2}{*}{ Trait } & \multirow{2}{*}{$\begin{array}{l}\text { Days to } \\
\text { anthesis }\end{array}$} & \multicolumn{7}{|c|}{ Harvest } & \multirow{2}{*}{$\begin{array}{c}\text { Lateral } \\
\text { branch } \\
\text { no. }\end{array}$} & \multirow{2}{*}{$\begin{array}{c}\text { Female } \\
\text { nodes } \\
(\text { no) }\end{array}$} \\
\hline & & Fruit no. & $\mathrm{L}: \mathrm{D}^{\mathrm{y}}$ & Fruit no. & $\mathrm{L}: \mathrm{D}$ & $\begin{array}{c}\text { Three } \\
\text { Fruit no. }\end{array}$ & Fruit no. & $\mathrm{L}: \mathrm{D}$ & & \\
\hline Days to anthesis & & $-0.14^{\mathrm{NS}}$ & $-0.17^{\mathrm{NS}}$ & $0.15^{\mathrm{NS}}$ & $-0.12^{\mathrm{NS}}$ & $0.05^{\mathrm{NS}}$ & $0.04^{\mathrm{NS}}$ & $-0.24 *$ & $-0.08^{\mathrm{NS}}$ & $0.01^{\mathrm{NS}}$ \\
\hline Fruit no. & $-0.07^{\mathrm{NS}}$ & & $-0.34^{* *}$ & $0.26^{*}$ & $0.19^{\mathrm{NS}}$ & $0.09^{\mathrm{NS}}$ & $0.48^{* *}$ & $0.00^{\mathrm{NS}}$ & $-0.31^{* *}$ & $0.65^{* *}$ \\
\hline $\mathrm{L}: \mathrm{D}$ & $-0.32^{* *}$ & $-0.04^{\mathrm{NS}}$ & & $-0.13^{\mathrm{NS}}$ & $0.25^{*}$ & $0.13^{\mathrm{NS}}$ & $-0.09^{\mathrm{NS}}$ & $0.63^{* *}$ & $0.53^{* *}$ & $-0.56^{* * *}$ \\
\hline L:D & $-0.36^{* *}$ & $-0.12^{\mathrm{NS}}$ & $0.49^{* * *}$ & $-0.09^{\mathrm{NS}}$ & & $0.10^{\mathrm{NS}}$ & $0.15^{\mathrm{NS}}$ & $0.78^{* * *}$ & $0.25^{*}$ & $-0.05^{\mathrm{NS}}$ \\
\hline \multicolumn{11}{|l|}{ Harvest 3} \\
\hline Fruit no. & $-0.13^{\mathrm{NS}}$ & $0.41^{* *}$ & $0.14^{\mathrm{NS}}$ & $0.51^{* *}$ & $0.16^{\mathrm{NS}}$ & & $0.88^{* * *}$ & $0.14^{\mathrm{NS}}$ & $0.34^{* *}$ & $-0.36^{* * *}$ \\
\hline \multicolumn{11}{|l|}{ Cumulative } \\
\hline Fruit no. & $-0.13^{\mathrm{NS}}$ & $0.83 * *$ & $0.06^{\mathrm{NS}}$ & $0.85^{* *}$ & $-0.01^{\mathrm{NS}}$ & $0.80^{* * *}$ & & $0.08^{\mathrm{NS}}$ & $0.13^{\mathrm{NS}}$ & $-0.01^{\mathrm{NS}}$ \\
\hline
\end{tabular}

${ }_{\mathrm{y}} \mathrm{L}: \mathrm{D}=$ length/diameter ratio of randomly selected fruits from 7 to 10 plants per experimental unit (line).

${ }^{\mathrm{x}}$ Average over three harvests.

Ns,**** Nonsignificant or significant at $P=0.05$ and 0.01 , respectively. 
Relatively high and consistent $R^{2}$ values ( 0.86 and 0.97$)$ for number of female nodes per plant were detected in both years (Table 2).

Correlation of Characters. Generally, there was agreement between years with regard to the value and direction of the correlation coefficients. Estimated coefficients among either fruit number per plant or L:D ratio in individual harvests and the remaining traits were less consistent and variable in direction depending on the year. However, these values were always positive and significant for pairwise comparisons within each trait.

Moderate to high and significant positive coefficients $(r=0.27$ to $r=0.48$ in 1999 and 2000, respectively) were obtained between number of lateral branches and cumulative L:D ratio and only in 1999 between number of female nodes and days to flowering ( $r=$ 0.49) (Table 5). The highest positive correlation between any two traits varied, and was dependent on year. The maximum coefficient in 1999 was observed between number of lateral branches and total number of fruit $(r=0.63)$ as well as between lateral branches and fruit number in the third harvest $(r=0.69)$. In 2000, the highest $r$ values were observed between number of lateral branches and L:D ratio over harvests $(r=0.48)$ as well as between the number of female nodes and the fruit number in the first harvest $(r=0.65)$. In both years, significant negative correlation coefficients $(r \geq-0.67)$ were detected between number of female nodes and lateral branch number, between number of female nodes and L:D ratio over harvests $(r \geq-0.34)$, and between $\mathrm{L}: \mathrm{D}$ ratio over harvests and days to anthesis $(r \geq-0.24)$ (Table 5).

\section{Discussion}

The GCA analysis provides estimates of the average performance of a line in hybrid combination (Sprague and Tatum, 1942). Such analyses are important because they provide an indication of the genetic differences that exist among lines being evaluated, and the importance of genes with largely additive effects. Additive and dominance effects have been shown to influence trait expression for fruit number in C. s. var. sativus and C. s. var. hardwickii lines (i.e., significant CGA and SCA) (El-Shawaf and Baker, 1981; Kupper and Staub, 1988; Lower et al., 1982) and multiple lateral branching (Serquen et al., 1997). The multiple, sequential fruiting cucumber lines, WI 5551 and $\mathrm{H}-19$, used in our study are the only processing type accessions available with such characteristics. The GCA of WI 5551 and $\mathrm{H}-19$ are different based on their performance when used in hybrid combination with GY14 and GY-7 (Table 3 and 4). Line WI 5551 conditions increased gynoecy and fruit number per plant in hybrid combinations while $\mathrm{H}-19$ increased fruit length(L:Dratio) and yield (Table 1). Thus, both appear to be effective in transmitting genes conditioning increased fruit and lateral branch number.

The SCA effects on yield components in our study varied with year (Table 4). This is not surprising because the environment has a large effect on the expression of yield components such as sex expression, days to anthesis, fruit number, and L:D ratio (Cramer and Wehner, 1998; Fredrick and Staub, 1989). Hybrids and germplasm derived from lines WI 5551 and H-19 should be evaluated in multiple environments.

Both GCA and SCA effects were significant determinants of the yield-related traits studied (Table 2). Furthermore, GCA was more important than SCA for most traits in both years (values $>0.75$, Table 2). Thus, selection procedures that emphasize the use of additive effects for the incorporation of yield-related traits should enhance gain from selection during cucumber improvement. The GCA analysis can be valuable for predicting hybrid performance in cucumber breeding. Similarly, the coefficient of determination $\left(R^{2}\right)$ provides an estimate of hybrids performance based on per se value of the parents (midparent values), and permits comparison with other predictors based on GCA. Because more than $80 \%$ of variability of the hybrids was predicted by midparent values in our study (Table 2 ), $R^{2}$ values can be relatively good predictors of hybrid performance when considering traits such as lateral branch number and number of female nodes per plant in cucumber.

Introgression of exotic alleles for improved yield residing in $C$. s. var. hardwickii has been an objective of several public cucumber breeding programs (Horst and Lower, 1978; Kupper and Staub, 1988; Wehner, 1989). This objective was achieved with the release of WI 5551 (Staub et. al., 1993), which on average provided a 1.5 fruit per plant increase when used in combination with elite inbred lines to produce hybrids (Fredrick and Staub, 1989). In our study, the cumulative fruit yield of WI 5551 was higher than H-19, and the hybrids constructed using WI 5551 were in general higher yielding than those made using H-19 (Table 1). These data and the GCA and SCA associated with WI 5551 in some hybrid combinations suggest that this inbred line has value for the development of high yielding elite lines.

Differential plant response to spacing, as it relates to reduced fruit yield and quality, suggests that caution must be exercised when extrapolating these results for estimating commercial application (Wehner, 1989). For instance, the yield advantage of $C$. $s$. var. hardwickii-derived germplasm is most pronounced at low plant densities (Frederick and Staub 1989), and the yield of C. s. var. sativus $\times$ C. s. var. hardwickii cross-progenies differ depending on generation (Delaney and Lower, 1987; Lower et al., 1982). Likewise, growing environment and plant density can affect days to anthesis and consequently early harvest fruit number in $C$. $S$. var hardwickii-derived germplasm (Frederick and Staub, 1989). Pedigree selection for disease resistance, gynoecy, branching, and sequential fruit set was exercised under relatively low plant densities (29,000 plants/ha) and multilocation testing in the development of the $C$. s. var. hardwickii-derived high yielding line, WI 5551. However, processed quality of WI 5551 derived hybrid fruit was commercially not acceptable in earlier studies (Fredrick and Staub, 1989). This deficiency might be overcome by using inbred elite lines (GY-7, GY14) with relatively large L:D values when introgressing yield and sex expression-associated genes present in WI 5551. It is clear, however, that selection in populations derived from hybrids in our study (e.g., backcross to GY-7 or GY14) should be directed towards improved fruit quality as well as yield potential.

Trait correlations need to be considered when developing high yielding elite germplasm from exotic sources. Moderate to large correlation coefficients were obtained between lateral branch number and fruit yield in C.s. var. hardwickii x elite hybrids and WI5551 X elite hybrids (Fredrick and Staub, 1989; Kupper and Staub, 1988). These associations were also detected in our study using different parental lines in combination with WI 5551 (Table 5). Such correlations have also been observed in $C$. s. var. sativus germplasm (Cramer and Wehner, 2000a, 2000b). However, the correlation between several yield-related traits (i.e., number of female nodes or days to anthesis) and fruit number per plant has generally been negative, low, and variable depending on season or planting conditions in this and other studies (Cramer and Wehner, 2000a, 2000b; Fredrick and Staub, 1989; Kupper and Staub, 1988), possibly due to the first fruit inhibition. Likewise, differences in magnitude and direction of correlations have been observed among yield component traits. These observations suggest that the genetic variability and performance of C.s. harwickii-related lines under different experimental conditions will determine the usefulness of yield 
component-related traits as selection factors during the improvement of total fruit number per plant in cucumber.

Selection for high lateral branch number per plant will likely lead to improved yield in both sativus and hardwickii-derived varieties (Cramer and Wehner, 2000a, 2000b; Fredrick and Staub, 1989; Kupper and Staub, 1988). The combining ability results associated with WI 5551 presented herein indicate that WI 5551 can transmit genes for increased fruit and lateral branch number as well as genes that condition gynoecy. Selection for gynoecy and lateral branch number is currently being applied to progeny of WI 5551-derived backcross populations $\left(\mathrm{BC}_{2}, \mathrm{BC}_{3}\right)$ with relatively large $\mathrm{L}$ : $\mathrm{D}$ ratios to produce high quality, high yielding breeding lines. It is unclear, however, whether selection in such populations will successfully overcome the negative attributes (e.g., small fruit, large seed cavities, etc.) initially contributed by $C$. s. var. hardwickii germplasm.

\section{Literature Cited}

Baker, R.J. 1978. Issues in diallel analysis. Crop Sci. 18:533-536.

Burrow, M.D. and J.G. Coors. 1994. Diallel: A microcomputer program for the simulation and analysis of diallel crosses. Agron. J. 86:154-158.

Cargill, G. 1962. Studies of factors affecting the yield and quality of cucumbers. I. Fruit length and fruit setting. Acta Agr. Sand. 12:355-362.

Comstock, R.E. and H.F. Robinson. 1948. The components of genetic variance in populations of biparental progenies and their use in estimating the average degree of dominance. Biometrics 4:254-266.

Cramer, S.C. and T.C. Wehner. 1998. Fruit yield and yield component means and correlations of four slicing cucumber populations improved through six to ten cycles of recurrent selection. J. Amer. Soc. Hort. Sci. 123:388-395.

Cramer, S.C. and T.C. Wehner. 2000a. Path analysis of the correlation between fruit number and plant traits of cucumber populations. HortScience 35:708-711.

Cramer, S.C. and T.C. Wehner. 2000b. Fruit yield and yield component correlations of four pickling cucumber populations. Cucurbit Genet. Coop. Rpt. 23:12-15.

Delaney, D.E. and R.L. Lower. 1987. Generation mean analysis of plant characteristics in crosses between two determinate cucumber lines and Cucumis sativus var. hardwickii. J. Amer. Soc. Hort. Sci. 112:707-711.

El-Shawaf, I.I.S. and L.R. Baker. 1981. Combining ability and genetic variances of $\mathrm{G} \times \mathrm{H} \mathrm{F}_{1}$ hybrids for parthenocarpic yield in gynoecious pickling cucumber for once over mechanical harvest. J. Amer. Soc. Hort. Sci. 106:365-370.

Fredrick, L.R. and J.E. Staub. 1989. Combining ability analyses of fruit yield and quality in near-homozygous lines derived from cucumber. J. Amer. Soc. Hort. Sci. 114:332-338.

Gharderi, A. and R.L. Lower. 1979. Heterosis and inbreeding depression of yield in populations derived from six crosses of cucumber. J. Amer. Soc. Hort. Sci. 104:564-567.

Gharderi, A. and R.L. Lower. 1981. Estimates for genetic variances for yield in cucumber. J. Amer. Soc. Hort. Sci. 106:237-239.

Goode, M.J., J.L. Bowers, and T.E. Morelock. 1989. Arkansas little-leaf cucumber. Annual Meeting Amer. Soc. Hort. Sci. Program and abstracts. 92:262.

Griffing, B. 1956. Concept of general and specific combining ability in relation to diallel crossing systems. Austral. J. Biol. Sci. 9:463-493.

Hallauer, A.R. and J.B. Miranda. 1981. Quantitative genetics in maize breeding. Iowa State Univ. Press, Ames.

Horst, E.K. and R.L. Lower. 1978. Cucumis hardwickii: A source of germplasm for the cucumber breeder. Cucurbit Genet. Coop. Rpt. 1:5.

Kupper, R.S. and J.E. Staub. 1988. Combining ability between lines of Cucumis sativus L. and Cucumis sativus var. hardwickii (R.) Alef. Euphytica 38:197-220.

Lower, R.L., J. Nienhuis, and C.H. Miller. 1982. Gene action and heterosis for yield and vegetative characteristics in a cross between a gynoecious pickling cucumber inbred and a Cucumis sativus var. hardwickii line. J. Amer. Soc. Hort. Sci. 107:75-78.

McCollum, J.P. 1934. Vegetative and reproductive responses associated with fruit development in cucumber. Cornell Univ. Agr. Expt. Sta. Memo. 163. Appl. Genet. 73:350-356.

Meglic, V., F.C. Serquen, and J.E. Staub. 1996. Genetic diversity in cucumber (Cucumis sativus L.): I. A reevaluation of the U.S. germplasm collection. Genet. Res. Crop Evol. 46:533-546.

Peterson, C.E. 1960. A gynoecious inbred line of cucumber. Mich. Agr. Expt. Sta. Quartly. Bul. 43:40-42.

SAS Institute. 1992. SAS/Stat user's guide. release 6.03 edition. SAS Inst., Cary, N.C.

Serquen, F.C., J. Bacher, and J.E. Staub. 1997. Genetic analysis of yield components in cucumber (Cucumis sativus L.) at low plant density. J. Amer. Soc. Hort. Sci. 122:522-528.

Simmonds, N.W. 1979. Principles of crop improvement. Longman Group Ltd., London.

Smith, O.S. and R.L. Lower. 1978. Field plot techniques for selecting increased once-over harvest yield in pickling cucumbers. J. Amer. Soc. Hort. Sci. 103:92-94.

Sprague, G.F. and L.A. Tatum. 1942. General vs. specific combining ability in single crosses of corn. J. Amer. Soc. Agron. 34:932-942.

Staub, J.E. and R.S. Kupper. 1985. Use of Cucumis sativus var. hardwickii germplasm in backcrosses with Cucumis sativus var. sativus. HortScience 20:436-438.

Staub, J.E, A. Gabert, and T.C. Wehner. 1996. Plant variety protection: A consideration of genetic relationships. HortScience 31:1086-1091.

Staub, J.E., C.E. Peterson, L.K. Crubaugh, and M.J. Palmer. 1993. Cucumber population WI 6383 and derived inbreds WI 5098 and WI 5551. HortScience 27:1340-1341.

Tiedjens, V.A. 1928. Sex ratios in cucumber flowers as effected by different conditions of soil and light. J. Agr. Res. 36:721-746.

U.S. Dept. of Agriculture. 1940, 1981, and 1998. Agricultural statistics. U.S. Government Printing Office, Wash., D.C.

Wehner, T.C. 1989. Breeding for improvement yield in cucumber, p. $323-$ 359. In: J. Janick (ed.). Plant breeding reviews. vol. 6. Wiley, New York. 